\title{
Unique chemical features of the peridotitic mantle below the Jericho kimberlite (Slave Craton, Northern Canada).
}

\author{
Kopylova, M. G. ${ }^{1}$, Russell, J. K. ${ }^{1}$, Cookenboo, H. ${ }^{2}$
}

1. Geological Sciences Division, Department of Earth and Ocean Science, The University of British Columbia,

Vancouver, Canada, V6T 1Z4

2. Canamera Geological Ltd., 399 Mountain Highway, North Vancouver, Canada, V7J 2K9

The varieties of upper mantle xenoliths recovered from the Jericho kimberlite resemble, for the most part, populations of xenoliths recovered from kimberlites of other cratons in their proportions, petrography and mineralogy. There are, however, substantive differences between Jericho peridotitic xenoliths and kimberlite-derived peridotites described from other cratons. There are three major unique chemical features of Jericho peridotitic xenoliths: i) an anomalously high proportion of chemically unequilibrated samples, ii) a distinct $\mathrm{Cr}$-enrichment in mineral chemistry observed in porphyroclastic peridotite relative to coarse peridotite, and iii) the presence of a well-defined and unique trend in compositions of pyrope that is less enriched in $\mathrm{Cr}$ relative to the common "lherzolitic" trend. These unique features of Jericho peridotites suggest substantive differences in the character of the underlying upper mantle relative to other cratonic mantle.

Almost half of the analysed samples of coarse and porphyroclastic peridotite are chemically unequilibrated; minerals show abundant between and within-grain chemical variation. The chemical variation is irregular, in that, individual grains show patchy zoning, generally restricted to the rims, and mineral chemistry does not always correlate with grain shape and origin (e.g., porphyroclast vs neoblast). The most heterogeneous minerals are clinopyroxene and garnet, the least - olivine. Garnet normally exhibits depletion of $\mathrm{CaO}(1.2 \mathrm{wt} \%)$ and $\mathrm{Cr}_{2} \mathrm{O}_{3}(2.5 \mathrm{wt} \%)$ towards rims. There are three main zoning patterns in clinopyroxene; all show a decrease in $\mathrm{Al}_{2} \mathrm{O}_{3}(0.5-1 \mathrm{wt} \%)$ and $\mathrm{Na}_{2} \mathrm{O}(0.5-1.5$ wt\%) rimwards and a corresponding increase in $\mathrm{SiO}_{2}$ and $\mathrm{MgO}$. Superimposed on this pattern are other chemical trends: (1) Ca-enrichment with Cr-depletion, (2) Ca-enrichment with little or no $\mathrm{Cr}$ enrichment, and (3) Fe-Ti enrichment. The overall chemical variations are: $2-3 \mathrm{wt} \% \mathrm{CaO}, 0.4-0.8$ wt $\% \mathrm{Cr}_{2} \mathrm{O}_{3}$, and $0.2-0.5 \mathrm{wt} \% \mathrm{FeO}$ and $\mathrm{TiO}_{2}$. In contrast, orthopyroxene rarely demonstrates zoning in $\mathrm{Al}, \mathrm{Cr}, \mathrm{Fe}$ and $\mathrm{Ca}$.

At least three processes are required to explain the observed chemical heterogeneity. Garnet growth, at the expense of clinopyroxene, can account for redistribution of $\mathrm{Ca}$ and $\mathrm{Al}$ between garnet and clinopyroxene (Sautter \& Harte, 1988). Trends 1 and 2 (above) are commonly associated with cooling, which is more pronounced in high-temperature specimens (Fig. 1). In contrast, trend 3 (FeTi-enrichment) is consistent with increased temperature and may derive from mantle-melt metasomatism (Harte et al., 1987; Smith \& Boyd, 1987 etc.). Although trend 3 is uncommon in Jericho peridotites, the cryptic signature of mantle metasomatism (Griffin et al., 1996) is evident in high and variable measured contents of $\mathrm{Y}(>10 \mathrm{ppm})$ and $\mathrm{Zr}(>30 \mathrm{ppm})$ in garnet.

Porphyroclastic peridotite from Jericho comprises minerals that are $\mathrm{Cr}$-rich or have distinct $\mathrm{Cr}$ zoning patterns compared to undeformed peridotite. These features of mineral chemistry have not been described in other suites of peridotitic xenoliths. Specifically, olivine from porphyroclastic peridotite is $\mathrm{Cr}\left(0.07 \mathrm{wt} \% \mathrm{Cr}_{2} \mathrm{O}_{3}\right)$ and $\mathrm{Ca}$-enriched $(0.04 \mathrm{wt} \% \mathrm{CaO})$. Similarly, orthopyroxene contains more $\mathrm{Cr}_{2} \mathrm{O}_{3}(>0.29 \mathrm{wt} \%)$ and $\mathrm{CaO}(>0.47 \mathrm{wt} \%)$ than orthopyroxene in coarse peridotite. Average concentrations of $\mathrm{Cr}_{2} \mathrm{O}_{3}$ in garnet are higher: $7.70 \pm 2.02(2 \sigma)$ wt $\%$ in porphyroclastic samples vs $4.17 \pm 1.26 \mathrm{wt} \%$ in coarse peridotite. Clinopyroxene in porphyroclastic rocks is not significantly $\mathrm{Cr}$-enriched relative to coarse peridiotite. However, the only zoning pattern which involves $\mathrm{Cr}$-enrichment (trend 2 ) is most-prevalent in clinopyroxene from sheared peridotite.

Two alternative explanations can account for the above characteristics of Jericho porphyroclastic peridotite. The relative $\mathrm{Cr}$-enrichment of these minerals could be an inherent primary feature associated with the absence of spinel and perhaps related to their deep origin. Conversely, the high- $\mathrm{Cr}$ character of minerals from porphyroclastic xenoliths may derive from a secondary process linked to deformation. The latter explanation is suggested by the fact that some clinopyroxene neoblasts and porphyroclast rims show $\mathrm{Cr}$-enrichment and by the presence, albeit rare, of olivine porphyroclasts that have retained their early chemistry depleted in $\mathrm{Cr}$ and $\mathrm{Ca}$. 


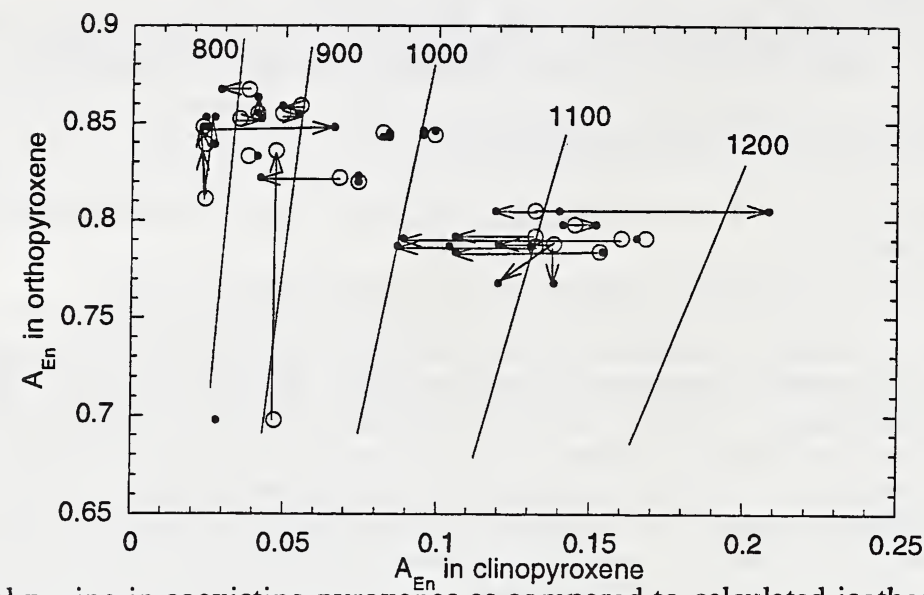

Fig. 1. Chemical zoning in coexisting pyroxennes as compared to calculated isotherms (Wells, 1977)

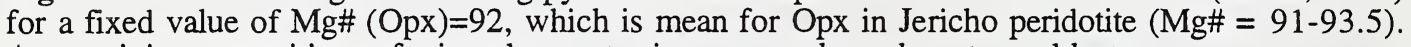
Arrows join compositions of mineral cores to rims, or porphyroclasts to neoblasts.

Garnet from Jericho xenoliths define an exotic trend in $\mathrm{Cr}$ and $\mathrm{Ca}$ content (Fig. 2). The trend shows less Cr-enrichment relative to the "Iherzolitic" trend common to pyrope from cratonic mantle. The exotic trend is observed in garnet from the Jericho heavy mineral concentrate and spinel-garnet peridotite and in concentrate garnet from the nearby Ranch Lake pipe (Cookenboo, 1996). The trend is ascribed to equilibration of garnet with a lherzolitic mineral assemblage that includes spinel. This is borne out by the fact that only garnet compositions from spinel-bearing garnet peridotite plot along this trend; all garnet compositions from spinel-absent peridotites plot on the "lherzolitic" trend. The rarity of this trend in pyrope compositions from other kimberlite bodies or from other suites of spinelgarnet peridotite xenoliths suggests that the presence of modal spinel alone, is insufficient to produce the "spinel-garnet equilibrium" trend. It appears that there is another, as of yet, unknown factor contributing to spinel-garnet equilibration. Equilibration with spinel affected not only garnet, but also clinopyroxene, which shows a negative $\mathrm{Mg}$-Cr correlation in Jericho spinel-garnet peridotite. A trend similar to the "spinel-garnet equilibrium" trend was reported for some spinel-garnet nodules from South Africa (Smith and Boyd, 1992) and was produced experimentally for natural lherzolite compositions between 900 and $1200^{\circ} \mathrm{C}$ and 3.3 - 6 Gpa (Brey et al., 1990; Brey, 1991).

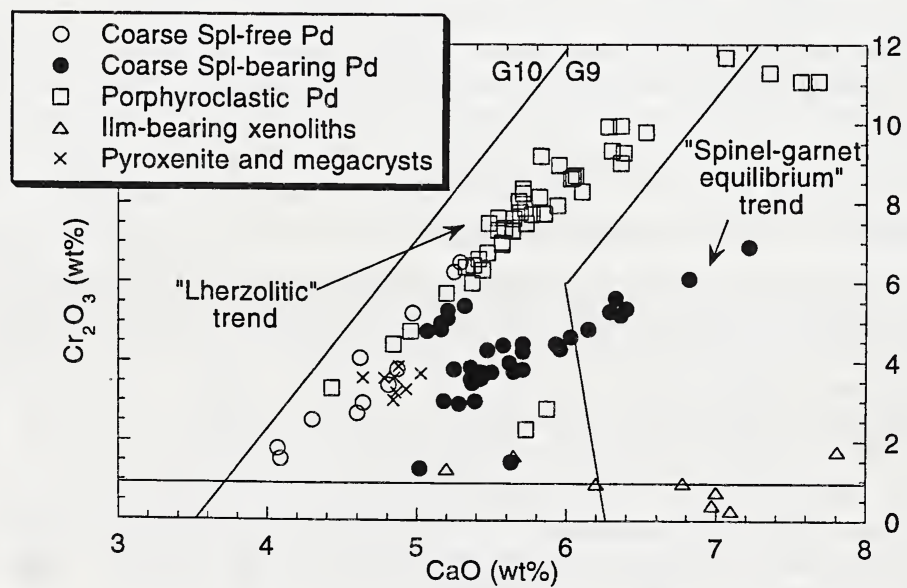

Fig. 2. Garnet compositions from Jericho peridotite and pyroxenite plotted as $\mathrm{Cr}_{2} \mathrm{O}_{3}-\mathrm{CaO}$. 


\section{References}

Brey, G.P., Kohler, T., and Nickel, K.G., 1990. Geothermobarometry in four-phase lherzolites I.Experimental results from 10 to $60 \mathrm{~kb}$ : Journal of Petrology, 31, p6, p. 1313-1352.

Brey, G., 1991. Fictive conductive geotherms beneath the Kaapvaal craton: Abstr. 5th Intern. Kimb. Conf., p. 23-25.

Cookenboo, H., 1996. Ranch Lake kimberlite in the Central Slave Craton: The mantle sample. The Gangue, Geol. Ássoc. of Canada, Miner. Deposits Div., Victoria, Canada, No. 52, 12-13

Griffin, W.L., Kaminsky, F.V., Ryan, C.G., O'Reilly, S.Y., Win, T.T., and Ilupin, I.P., 1996. Thermal state and composition of the lithospheric mantle beneath the Daldyn kimberlite field, Yakutia: Tectonophysics, 262, p. 19-33.

Harte, B., Winterburn, P.A., and Gurney, J.J., 1987. Metasomatic and enrichment phenomena in garnet peridotite facies mantle xenoliths from the Matsoku kimberlite pipe, Lesotho. In: Menzies, M.A., and Hawkesworth, C.J. (ed) Mantle metasomatism, Academic Press, p. 145-220.

Sautter, V. and Harte, B., 1988. Diffusion gradients in an eclogite xenolith from Roberts Victor kimberlite Pipe: 1. Mechanism and evolution of garnet exsolution in $\mathrm{Al}_{2} \mathrm{O}_{3}$-rich clinopyroxene: Journal of Petrology, 29, p6, p. 1325-1352.

Smith, D. and Boyd, F.R., 1987. Compositional hetegeneities in a high-temperature lherzolite nodule and implications for mantle processes. In: Nixon PH (ed) Mantle xenoliths. New York: John Wiley, p. 551-561.

Smith, D.and Boyd, F.R., 1992. Compositional zonation in garnets in peridotite xenoliths. Contributions to Mineralogy and Petrology, 112, p. 134-147.

Wells, P. R. A., 1977. Pyroxene thermometry in simple and cơmplex systems. Mineralogy and Petrology, 62: 2, p. 129-139. 